\title{
STUDIES ON WATERPROOFING OF CELLULOSE AND APPUCATION OF SURFACTANTS.
}

By Toshikazu Fujikura and Kenji Iwakura.

(Faculty of Engineering, Yamagata University, Yonezawa City. Yamagata Prefecture, Japan)

It is difficult to spread the repellent agent uniformly on the surface of the substrate using the dilute solution which contains the least amount of repellent agent required theoretically, and the defects in the layer will result in insufficient repellency. Therefore, the excess amount of repellent agent is used for practical treatments.

The effects of dilution of the repellent solution and the application of surfactants on waterproofing were investigated, and the following results were obtained;

(1) The contact angle between a water drop and cellophane, and its resistance against washing and wearing does not deteriorate untill the concentration of repellent agent decreases to about a tenth of usually applied concentration. Below this range, the fluorochemical agent exhibits more rapid decrease of the contact angle than the silicone.

(2) The repellent effects are improved by repeated treatments with the solution of unsufficient concentration.

(3) The pretreatment with the solution of surfactant followed by drying over $100^{\circ} \mathrm{C}$, recovers the deterioration due to the dilution of repellent agent and this recovery showed maximum between $0.001 \%$ and $0.01 \%$ of surfactant concentration. At the higher concentration, the levelling effect of surfactant fixed on the surface of substrate might be outweighed by the hydrophilic effect of the surplus surfactant.

(Received June 27, 1967)

\section{1. 緒言}

徤来行なわれている防止剂処理方法では数・゙ーセント の漕度を用いている。しかるに発水作用は界面現象であ るから表面火必要最小限の防承剂の均一層当形成すれば

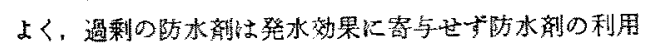
效率を低めていると考无られる。こで防水用の節約を 图るとは，浴濃度をうすかることが考古られるが，この

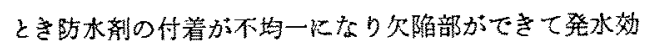
果が低下する危險があ。

これに対し怒理を反復したり界面活性剂を利用寸れば 付着家约一にすることが可能と考兵られる。しかし界面

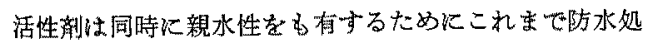
理汇性有害とされていだ。圠とえば Wayland らは被

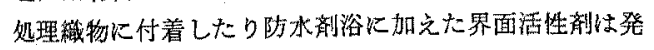
水效果を阻害し，その程度はシリコーン系叔よびフッ素
系の防林剂において著しいことを報告している。

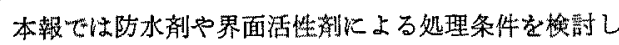

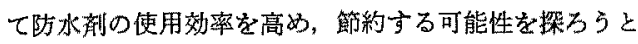
する安のでめる。このためだハンフィルム基材と し，比較的高価なシりコーン系括よびフッ素系の跭水剂

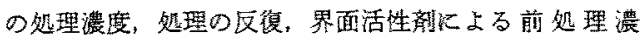
度, 乾嬠温度, 後処理などの発水効果や堅年性に対方 影掣を接触角測定により检討した。

\section{2. 実験}

\section{$2 \cdot 1$ 試 料}

防水绪はフッ素系としてポリアクリル酸のパーフルオ

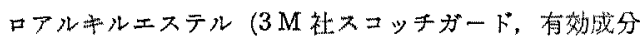

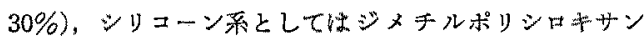
とメキルハイドロジェンがりシロキサン（日本すイヒホ ールド社, ノランシリコーンコンク，有效成分 $60 \%$ ) 
を使用し，界面活性剤はアルキルピコリニウムクロライ ド（第一工業製蔡，カチオゲン），高級アルコール硫酸 エステルッーダ（同社，モノダン）拉よびポリエキレン グリコールアルキルエーテル（同社，ノイダン HC) を 使用した。基材としてセロハン（厚さ $0.03 \mathrm{~mm}$ ) る セトンで洗浄して用いた。

\section{$2 \cdot 2$ 方 法}

防水処理条件基材を所定濃度の浴に $60^{\circ} \mathrm{C} て ゙ 15$ 分 浸し，絞り率 $50 \% ， 80^{\circ} \mathrm{C} て ゙ 4$ 分乾燥， $130^{\circ} \mathrm{C} て ゙ 4$ 分高 熱处理し，洗浄乾燥した。

界面活性剂化よる処理条件は $60^{\circ} \mathrm{C}$ で 15 分浸子き， 茭り率 $50 \%$ に絞り，乾燥後 $130^{\circ} \mathrm{C}$ で高温加熱した。

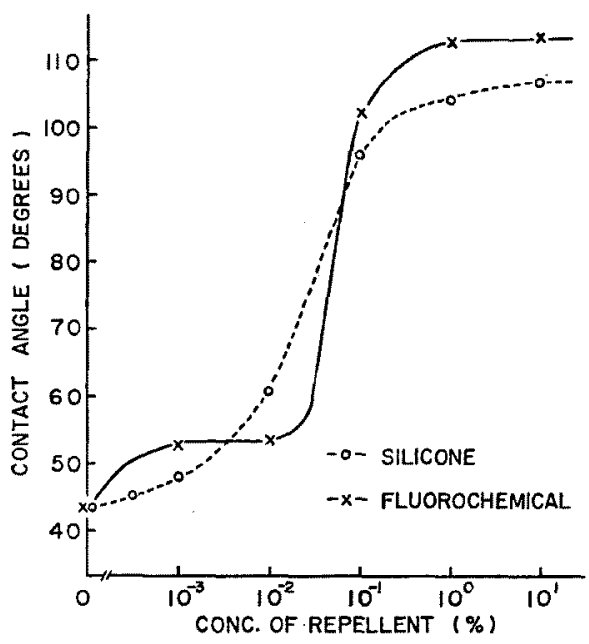

Fig. 1. Relations between concentration of repellents and contact angle.

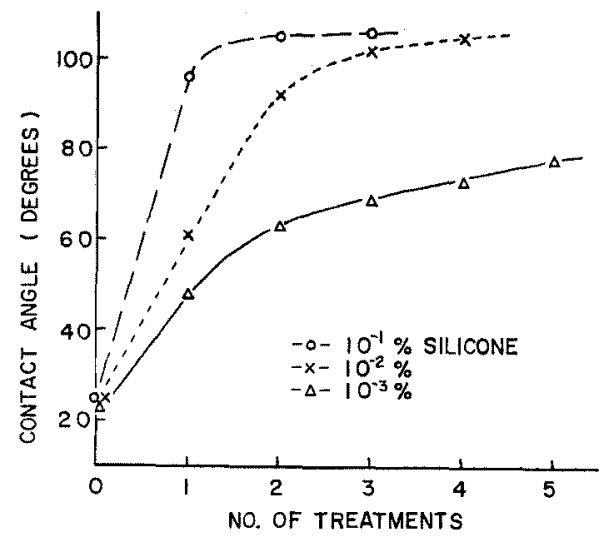

Fig. 2. Effects of repeated treatments with dilute silicone repellent on contact angle.
な括処理フィルムにひずみが生じるのを防ぐため加熱 はすべて温度調節をしたアイロンを使用した。

発水効果の評何法として陚料フィルム上につくった液 滴の幅と高さをゴニオメータ付顕微鏡で測り接触角を算 出した。測定温度は $20^{\circ} \mathrm{C}$ と , 澌定容器内を同一液体 の蒸気で飽和状態に保った。同一武料につき 6 個所にお。 いて測定し，平均値をとった。

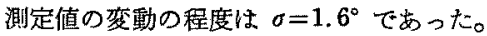

処理フィルムをJIS の染色物の堅牢度試験に準ずる条 件て摩擦および洗たくを行ない，発水効果の堅牢性を調 ベた。

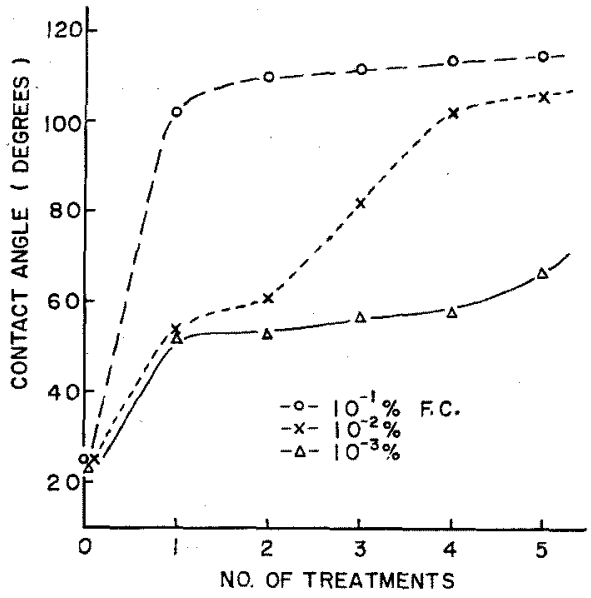

Fig. 3. Effects of repeated treatments with dilute fuorochemical repellent on contact angle.

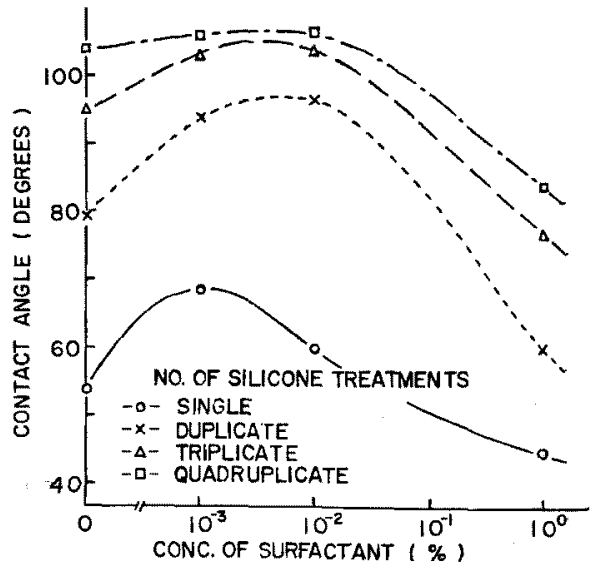

Fig. 4. Effects of pretreatment with cationic surfactant on waterproofing with $0.01 \%$ silicone. 


\section{3. 結}

果

\section{1 防水処理浴㶇度低下の影響}

防水剤の処理浴濃度を順论うするたときの接触角の变 化を図1亿示した。シリコーン系，フッ素系ともに浴濃

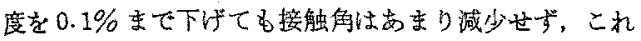
よりらすくなるとフッ素系の場合は急激に未処理の值ま て減少し、シリニーン柔では比较的りるやかに減少し $t_{0}$

\section{2 防水起理の反復}

接触角で低下する低湄度の浴による处理资反復したと きの発水效果を图2，四3に示した。浴浱度が著しくう すくとも，処理をくり返し行ならと高濃度の場合と同等 近くまで発办效果が向上した。処理回数はフッ素系より

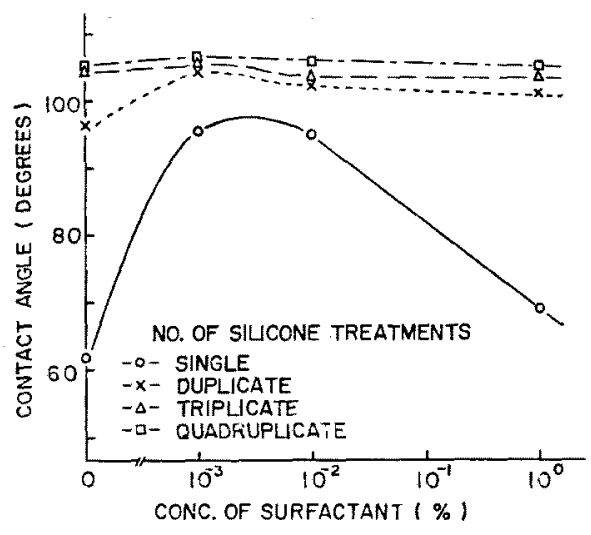

Fig. 5. Effects of pretreatment with anionic surfactant on waterproofing with $0.01 \%$ silicone.

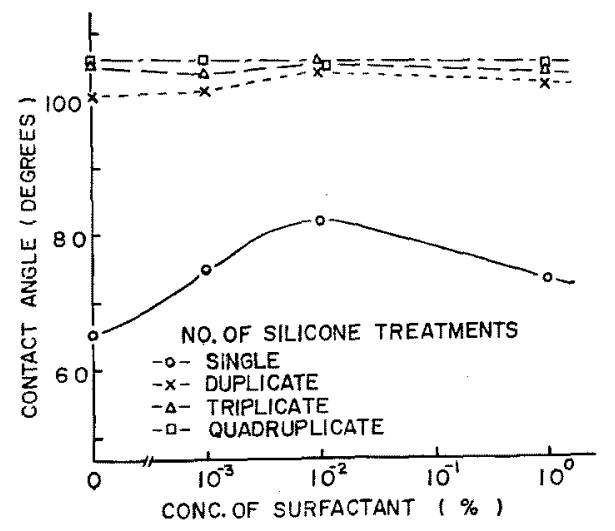

Fig. 6. Effects of pretreatment with nonionic surfactant on waterproofing with $0.01 \%$ silicone.
むシリコーン系のものが少なくてよかった。低浱度浴で 反復処理すると，これに用いた防水剂の合計飞相当する 量を加えた高濃度の浴で 1 回处理したときより10〜30 度程高い接触角を示した。

\section{$3 \cdot 3$ 界面活性剂による前処理}

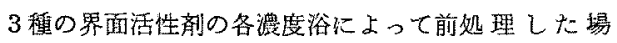

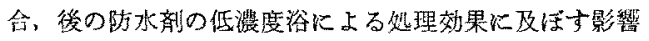
について国4〜图9に示した。な叔この場合, 界面活性

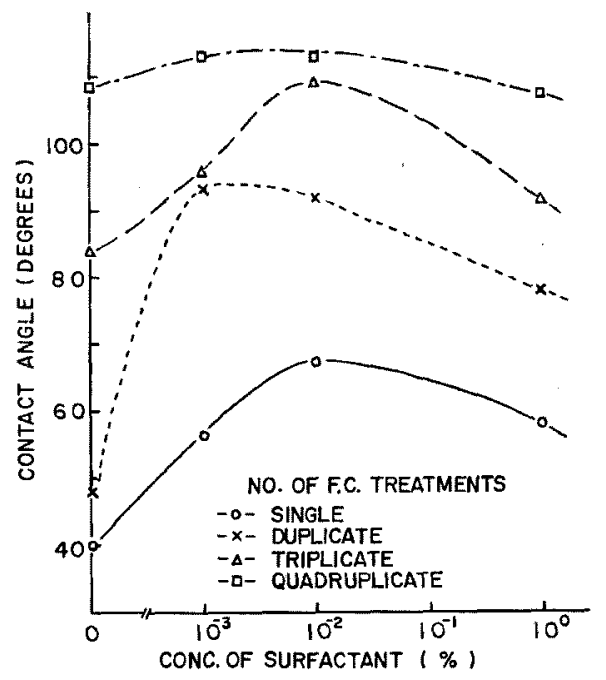

Fig. 7. Effects of pretreatment with cationic surfactant on waterproofing with $0.01 \%$ fluorochemical.

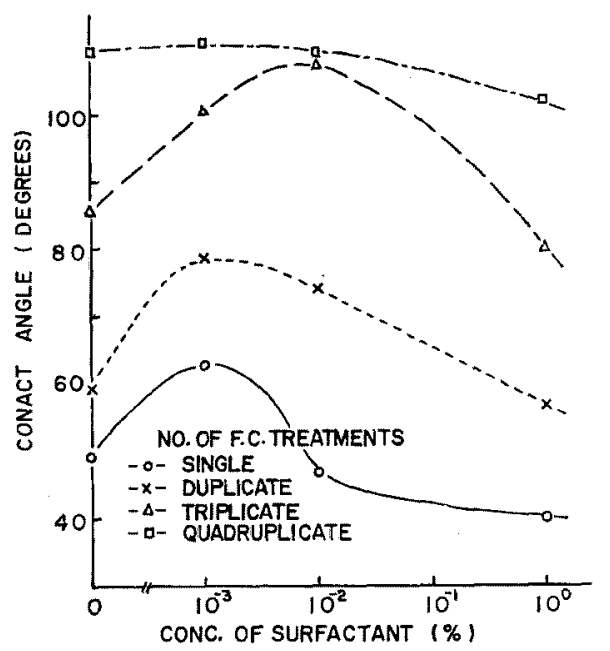

Fig. 8. Effects of pretreatment with anionic surfactant on waterproofing with $0.01 \%$ fluorochemical. 
剂で前処琴しないセロハンについても条件を同じにする ため同一条件で水に浸せきし加熱乾嬠を行なったので図 2, 図3の值より高目の接螌角を示した。これは上記の 処理によりセロハンに付着していた不純物が除去された ためであるうと思われる。両防水剂とも先に被処理物に 界面活性剂を付着させ加熱乾燥して蛒くと，低濃度であ ればその種類にかかからず後の発水処理效果は向上し， 前処理浴濃度が 0.001〜0.01\%のとこちでその効果は極 大を示すが，それ以上では次第に低下して高濃度になる とかえって防水剂による処理效果を阻害する傾向を示し た。この前処理に相当する量の界面活性剤老防水処理浴

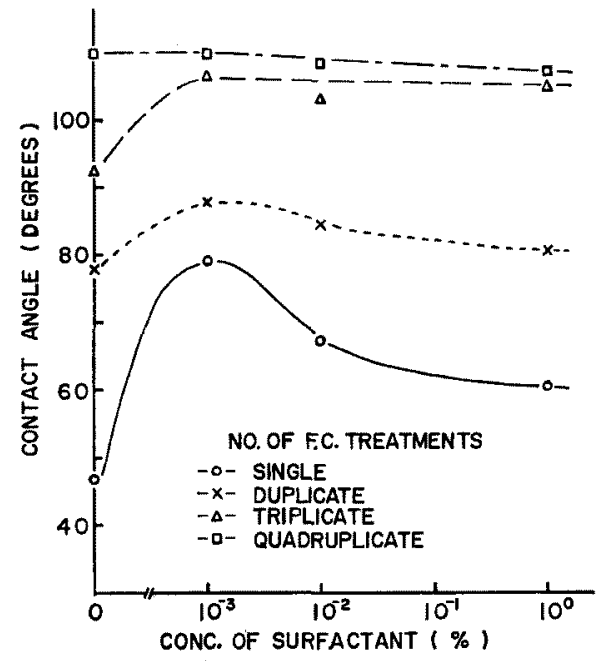

Fig. 9. Effects of pretreatment with nonionic surfactant on waterproofing with $0.01 \%$ fluoroshemical.

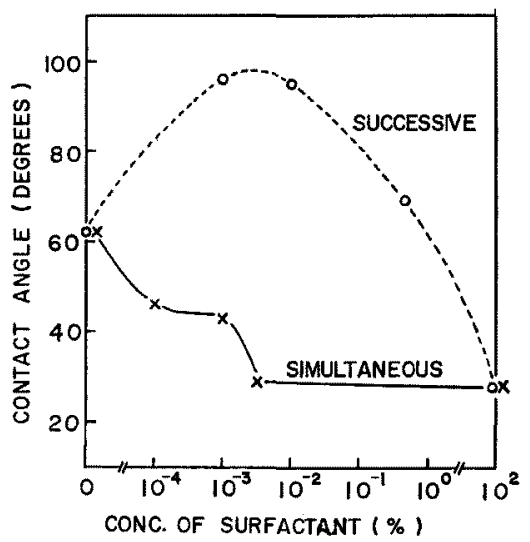

Fig. 10. Comparison between simultaneous and successive treatment with surfactant and $0.01 \%$ silicone.
に加えて 1 浴で処理すると図 10 に示すように逆に発水 性は阻書され，文献の結果と同じであっだ。前処理の 際の乾燥温度の影搖を及ると図 11 のうに $100^{\circ} \mathrm{C}$ 以上 にならないと上述の効果は現われなかった。界面活性剂 と防水剤で交代に処理した場合は图 12 のよらな結果を

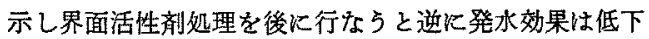
乙た。

\section{4 発水処理物の堅牢性}

シリコーン系防水剤の単分子層形成濃度以上の浴で処 理したフィルムの発水効果の堅牢性は図 13, 図 14 に示 すよ5に, 浴濃度を 1/10 K下げても, 防水性の下らな い濃度であれば，耐摩擦性，酎洗たく性ともあまり差が

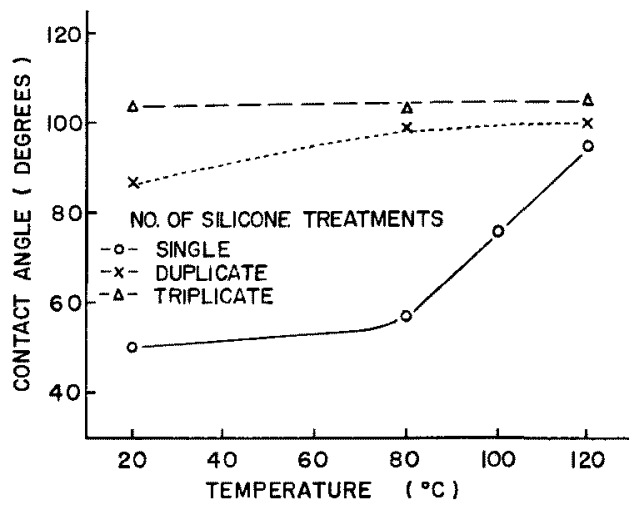

Fig. 11. Effects of pretreatment temperature with surfactant on waterproofing with $0.01 \%$ silicone.

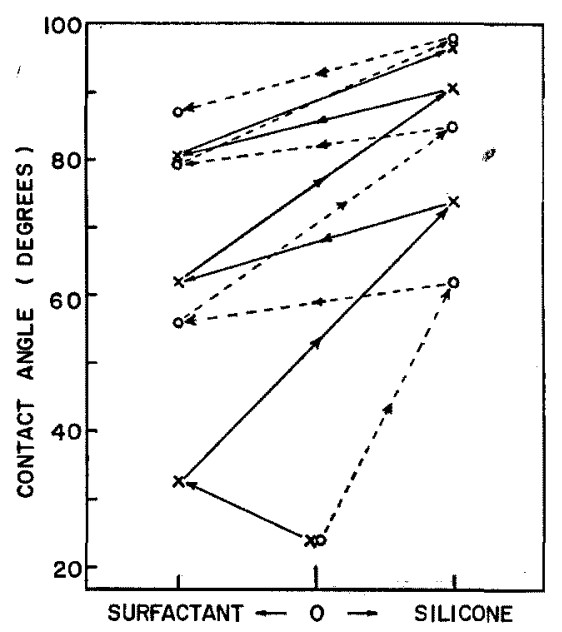

Fig. 12. Effects of alternating treatments with sillicone and surfactant on contact angle.

In $0 \cdots \cdots$ series, silicone was used at first. (n $x-x$ series, surfactant was used at first. 


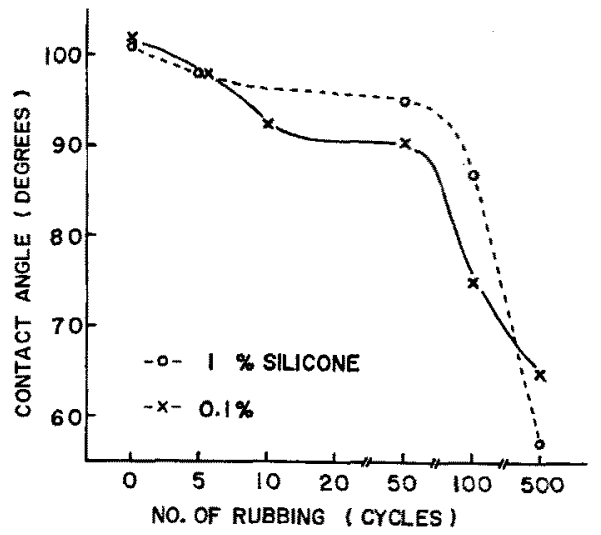

Fig. 13. Wear resistance of films treated with silicone repellent

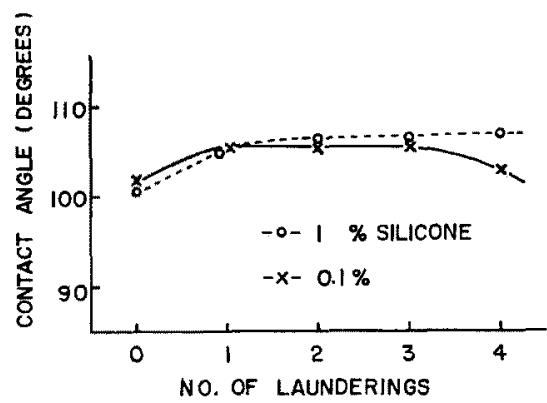

Fig. 14. Laundering resistance of films treated with silicone repellent.

証められなかった。このことから被越理物表面を均一に

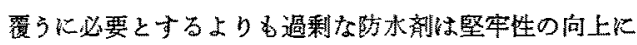
あまり貢献しないと思われるから反復処理中界面活性剂 の利用により低濃度浴から防水層を形成する場合でると れが均一で少し余裕があれば堅察性は下り難いと考えら れる。

\section{4. 考察}

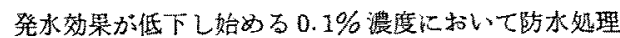
主る場合にフィルムの表面以均一代着子る防水層の厚 さを脚註のよらに简略化した前提て近似計算するとシり コーソ系では約 $50 \mathrm{~A}, 7 ッ$ 素采は利 $25 \mathrm{~A}$ となる一方, L.L.Heffner $5^{2)}$ Kよるとフッ素系の防水唷は团 15 の ように表面に执いてフッ素置換された長い側鎖が処理面 と垂直に配列し立体的な粗造をとり単分子層としての厚 さは約 $15 \mathrm{~A}$ 程磨ぜする。シリコーン系のbのは平面的

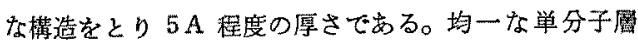

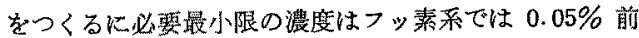
後、シリコーン䒩は $0.01 \%$ 前後となるが，原さの不陶<smiles>CCC(CC(CC(CC(C)C(=O)OCC(C)(C)C)C(=O)OCC(F)(F)F)C(=O)OCC(F)(F)F)C(F)(F)F</smiles>

Fig. 15. Structures of (A) fluorochemical and (B) silicone repellent

一があるため0.1\%以下になると防水剂層比欠陷部が生 じそれぞれ発办性が低下し始めると考充られる。ジ二 一ン系の方は主鑛方処理面上に横たすり，加名合って いると思かれるからうすくなってる主鎖コイルが搪がる ために防水層の欠陥部が急に大きくならす，発水性の低 下は比較的緩慢になるすのと考学る。

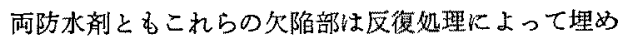
られて発水性を高めるが反面において先比付着した防水 郕との反発作用に上り後の防水剂の付着が站げられ不均 一之なり所要量が増加する危険性が多り,さらに高熱処 理のくり返しによる熱消費の増大や材料の熱変化が起こ るなど実用上問題があるう。

界面活性剂の作用として，Wayland らりに上る文献 と同椂に防水浴汇同時添加したときは有害であることは

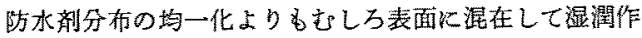

洼：フィルムの總乾重量 $F(\mathrm{~g})$ ，処理前風乾フィルム

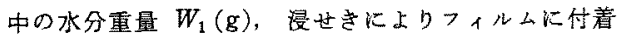
する液重量 $W_{2}(\mathrm{~g})$, 校りにより排除さ礼る液重量 $W_{3}(g)$ ，とすると

$$
\begin{array}{ll}
\text { 風乾フィルム重量 } & W_{0}=F+W_{1} \\
\text { 漫せき後フィル重量 } & W_{p}=\left(F+W_{1}\right)+W_{2} \\
\text { 校り後フィルム重量 } & W=\left(F+W_{1}+W_{2}\right)-W_{3} \\
& \therefore
\end{array}
$$

防水処理浴濃度 $C_{1}$, 校りにより排除される夜濃度 $C_{2}$

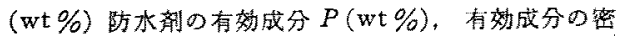

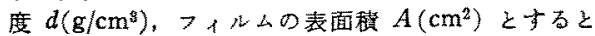

付着防水剂重量

$$
Q=\left\{c\left(W_{2}-W_{3}\right)+W_{3}\left(C_{1}-C_{2}\right)\right\} \cdot P
$$

吸着を無視し， $C_{1}=C_{2}=C$ と仮空すると $Q=C\left(W_{2}-W_{3}\right) \cdot P=c\left(W-W_{0}\right) \cdot P$

防水用周の厚さ $t(\mathrm{~cm})$ は次式で数わされる

$$
t=\frac{c\left(W-W_{0}\right) \cdot P}{A \cdot d} \times 10^{4}
$$

たたし処理浴からの選択的吸着和占びフィルム内部人 入ることを無視していることなどのため辨密ではな く，大略の值にとどまるすのである。 
用が強く現われることによると考光られる。また界面活 性剂で後処理したときは表面㲹存在して湿潤作用を示吉 ものであるら。しかし界面活性剂で前処理し加熱乾燥し たときはセロハンの表面に固定されてプライマーのよう な效果と後で付着する防水剂の層を均一化して，少量で

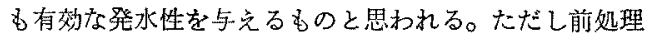
ナる場合でる界面活性剂浴洪度が高く付着量が多くなる と表面涀われて湿潤性を示して效泪を下げ，また前処 理後の乾燥温度が低いと固定が弱〈防水激之混在して発 办性を下げると考える。

このとき非イオン性と示してあるシリコーン系防水剂

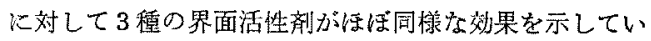
る。フッ菜系氾括いてる界面活性剂のイオン性による差 違があまり認如られないことからシリコーンと同様と思

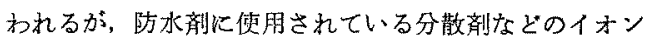
性が明らがされていないのでその作用については確か なことはいえない。

以上のことから適当な潡度の界面活性剂浴で前好理し た後加熱乾燥すれば，少量の防水剤で有効な発水効果を 与克ることができ，処理剤の利用効率を高好る可能性が あると考觉る。

防水被膜の堅牢性は理諭的に必要とするよりも過剩の 防水倣を使用しても仼とんど向上しない上うであるが， 本実験はフィルムで行なっているので織物の場合はな拉 㛟討を要する。

$$
\text { 5. 結 言 }
$$

（1）防水加工で防水剂濃度を従来の $1 / 10$ 程度まで
下げても発水性浊まり変わらないが，それ以下になる と接触解が減少する。その際フッ素系防水剂では低下が 急湤であるがシリコーン采ではやや䗅慢である。

（2）低い接触角しか与兄ない低濃度浴でる処理を反 復すると発水効果は通常浱度程度まで回復する。

（3）渙当濃度の界面活性郕浴で前処理し高温颙燥す ると低滥度の趽水剂浴からでもすぐれた発水性を付与す ることができるしかし界面活性剤を防水剂処理浴化添 加したとき特よび前処理の際の乾燥温度が低いときは逆 飞発水効果を阻害寸る傾向がある。

（4）これ訬量の界面活性剂が高温過熱炕上り表面 に固定され，後の防水剂の付着を均一にする作用をなし 自身は防水剂の層で完全飞蕧われて発水性を阻害するこ とがなくなるためであるらと思われる。

（5）以上の点からみて，防水戍処理浴濃度て下げて る，均一飞必要最小限の防水戍層を形式することがで き，処理剤を節約する可能性がある。

付 記

昭和 41 年瀻維 7 学会連合秋期研究発表会 昭和 41 年 10 月 28 日 東京, 文化女子大学

て諘演したものである。

\section{文献}

1) R. L. Wayland JR. Б; Am. Dyestuff Reptr., 52, 1059 (1963)

2) L. L. Heffner b; Am. Dyestuff Reptr., 52, 82 (1963) 